Available online at: http://ejournal-balitbang.kkp.go.id/index.php/iaj

\title{
SURVEILLANCE OF WHITE SPOT SYNDROME VIRUS (WSSV) AND MYONECROSIS VIRUS (IMNV) INFECTIONS IN CULTURED Litopenaeus vannamei
}

\author{
Isti Koesharyani" , Ariani Andayani, Ulfah Fayumi, and Ketut Sugama \\ *) Research Center for Fisheries \\ Gedung BRSDMKP II, JI. Pasir Putih II, Ancol Timur 14430, Jakarta
}

(Received 18 April 2018; Final revised 23 October 2018; Accepted 23 October 2018)

\begin{abstract}
Disease surveillance programs will provide updated information on the distribution of diseases which allows proper development of mitigation and prevention strategies. WSSV and IM NV viruses are the most threatening diseases in shrimp and have affected the global shrimp farming industries. The present study was conducted to investigate the prevalence of WSSV and IMNV in three different locations of shrimp farms of South Sulawesi, West Nusa Tenggara and West Jawa. Samples of shrimp Litopenaeus vannamei were randomly collected from 20 active shrimp farms in the locations and five samples of postlarvae (PL) that were stocked in ponds. Tissue samples of the shrimp and whole body of PL were preserved in ethanol $90 \%$

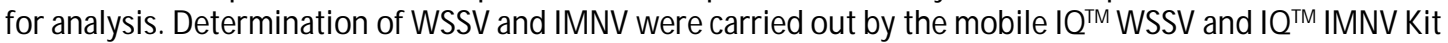
POCKIT Systems. The results showed that the prevalence of WSSV was 30\%(6/20) and IM NV was 20\%(4/20), while on PL was $40 \%(2 / 5)$. The result revealed that the South Sulawesi (Takalar) samples were positive only for WSSV while West Java (Panimbang) samples were positive only for IMNV. A follow-up study predicted that both viruses were transmitted from the PLs. The present study clearly confirmed that viruses were transmitted from PLs that were not free from either WSSV or IMNV. Therefore, a biosurveillance program is strongly recommended to be implemented in order to avoid the spread of the viral disease to other locations within Indonesia.
\end{abstract}

\section{KEYWORDS: infectious; WSSV; IMNV; Litopenaeus vanname; IQ $^{\text {TM }}$ Kit pockit}

\section{INTRODUCTION}

Two important viral pathogens, white spot syndrome virus (WSSV) and myonecrosis virus (IMNV) have been reported in Indonesia (Senapin et al., 2007; Taukhid \& Nur'aini, 2009; Ferasyi et al., 2015). Both virus diseases are the most important shrimp diseases in Indonesia. They affect most of commercially cultured Tiger and vannamei shrimps (Senapin et al., 2011; Octovianus et al., 2015). The first report of WSSV was in Taiwan 1992 (Chen, 1995) and was reported in China in 1993 by Huang et al. (1995) and spread worldwide ever since. The IM NV outbreak was first recorded in Brazil in South America (Lightner et al., 2004), followed by Indonesia in Asia (Senapin et al., 2007; Taukhid \& Nur'aini, 2009). So far, there were

\footnotetext{
\# Correspondence: Research Center for Fisheries. Gedung BRSDMKP II, JI. Pasir Putih II, Ancol Timur 14430, Jakarta Utara, Indonesia Phone: + 622164700928 E-mail: istisugama@yahoo.com
}

no reports about IMNV disease from other places found but as the seeds are procured from these countries. WSSV and IMNV have resulted in heavy mortalities and consequently production losses to the shrimp culture industry not only in Indonesia but also in many countries in Asia and Latin America (Sanapin et al., 2011; Arafani et al., 2016). WSSV is extremely virulent with a wide host range of shrimp including Penaeus monodon, Litopenaeus vannamei, and Penaeus stylirostris and targets various tissues of ectodermal and mesodermal origin (Mahardika et al., 2004; Dantas et al., 2015). While IMNV mostly infects L. vannamei and may cause $100 \%$ mortality in case of a late handling and an early harvest. All sizes of shrimp can be infected by WSSV or IMNV in all kinds of aquaculture systems (extensive, semi-intensive and intensive and super intensive both larva and adult shrimp (Karunasagar et al., 1997; Kilawati \& Maimunah, 2015).

Disease surveillance plays an important role to predict, designate, and manage disease outbreak in shrimp culture. Active surveillance for potential viral 
pathogens is the core of mitigation measures in case of viral disease outbreaks. Surveillance ecosystems are established in order to substantiate the disease status of the area or even a country (OIE, 2010).

An excellent structured and planned strategy for all-around surveillance is necessary for a pilot-scale and long-term study in identifying and reporting pathogens. For this, cultured shrimps have to be tested at various levels at every stage of farming in order to identify any probable threats. A regular or periodic study in farms also is also necessary to trace pathogens that can survive long in the pond sediments and thereby provides ample time for planning remedial and management strategies. The present study was conducted to investigate the prevalence of WSSV and IM NV infections in three different locations of shrimp farms of South Sulawesi, West Nusa Tenggara and West Java. The results of the research are expected to serve as a reference in the prevention of viral diseases outbreaks. The present study also provides insights to the shrimp aquaculture industries to increase their awareness of the importance of disease surveillance and develop preventive strategies against viral diseases. Infectious of WSSV and IMNV are an Office International des Epizooties (OIE) listed penaeid shrimp disease (Flegel, 2006; Lightner, 2011; OIE, 2015).

\section{MATERIAL AND METHODS}

The first field survey involved a random collection of cultured shrimp from three farms at each different location i.e. South Sulawesi (Barru and Takalar Districts), West Nusa Tenggara (Sumbawa District) and West Jawa (Panimbang, Lebak District). The first field survey was carried out between April-July 2017 in active shrimp ponds. The second field survey also randomly collected samples of cultured shrimp at the same locations but in different shrimp farms that lasted from September to December 2017. In both field surveys, shrimp samples were also collected if there were clinical signs of diseases observed in the cultured shrimp and noted the duration of culture (DOC). Samples of postlarvae (PL) stocked in the ponds of Takalar and Panimbang were also collected in order to check any possible transmission of both viral diseases. Details of sampling locations, dates, sample codes, DOCs, tissues, and number of samples collected are presented in Table 1 . A total of 25 samples (20 adults and 5 PLs) collected from the surveyed locations consisting of 335 individual shrimps were used in the virus detection analysis. The tissue samples of shrimp were firstly checked for visual clinical signs of virus infection following Nunan \& Lightner (2011) description. Afterward, each $10 \mathrm{~g}$ of the tissue samples of shrimp and the whole body of postlarvae (PL) was immersed in ethanol $90 \%$ before tested for WSSV using IQ Plus ${ }^{\top M}$ WSSV and RNALater ${ }^{\circledR}$ (Qiagen) before tested for IMNV using IMNV Kit POCKIT Systems. Both identification kit systems have been certified by the Office International des Epizooties (OIE).

\section{Extraction of Nucleic Acid (DNA and RNA)}

Extraction and amplification of Nucleic acids (DNA and RNA) for WSSV and IMNV detections followed the protocols described in the kits. All materials, solutions, and accessories were provided in the IQ Plus ${ }^{\mathrm{TM}}$ with POCKIT systems for the detection of WSSV and IMNV. The tissue samples of pleopods $(50 \mathrm{mg})$ or 10 whole bodies of PL were used for the extraction. The tissues were placed in a $1.5 \mathrm{~mL}$ microtube and filled with $500 \mu \mathrm{L}$ Solution-1 (lysis solution provided in the kit). A grinder was used to grind the sample directly in the tube. Afterward, The sample was mixed with $500 \mu \mathrm{L}$ Solution-2 (with ethanol) and spun for 1 min. The produced supernatant was transferred to the spun column and the collection tube set and respun for $1 \mathrm{~min}$. The solution was then discarded through flow-through from the collection tube whereas the supernatant was reassembled from the collection tube to the spun column. Of $500 \mu \mathrm{L}$ of Solution- 2 was added into the spun column and collection tube set, spin for 3 min., and discarded via the flow-through. The column was transferred to a fresh $1.5 \mathrm{~mL}$ centrifuge tube then added with $200 \mu \mathrm{L}$ Solution-3 into the spun column and spun for 1 min. The nucleic acid (DNA/RNA) was diluted into the tube and ready to be used for the amplification process.

\section{Amplification}

The IQ Plus ${ }^{\top M}$ POCKIT for WSSV and IMNV detection came with a ready Premix Pack. The first detection step was preparing the required vials according to the number of samples to be analyzed. Each vial cup was added with $50 \mu \mathrm{L}$ Premix buffer B to re-suspend the mix pellets (containing dNTPs, specific primers, fluorescent probes, and enzyme). Samples of the previously prepared DNA/RNA extract samples and positive control were separately collected and dissolved into different premix tubes using inoculation loops, mixed well, and spun slowly. The sample and positive control were transferred into the R-tubes, placed in a holder, and spun for 10 seconds. The POCKIT ${ }^{\mathrm{TM}}$ Nucleic Acid Analyzer was turned on and completed a self-testing for $5 \mathrm{~min}$. The marked wavelengths of $520 \mathrm{~nm}+550 \mathrm{~nm}$ were selected for further analysis as mentioned in the manual. After the system ready, the result was displayed and the holder containing the R-tubes was placed into the reaction 
Table1. Samples of L. vannamei for WSSV and IMNV analyses collected from different farm locations

\begin{tabular}{|c|c|c|c|c|c|c|}
\hline \multicolumn{2}{|c|}{ Location } & \multirow{3}{*}{$\begin{array}{c}\begin{array}{c}\text { Date of } \\
\text { sampling } 2017\end{array} \\
\text { April, } 24\end{array}$} & \multirow{3}{*}{$\begin{array}{c}\text { Sample code } \\
\text { BAA-1 } \\
\text { BAA-2 }\end{array}$} & \multirow{3}{*}{$\begin{array}{c}\begin{array}{c}\text { Days of culture (DOC) } \\
\text { when sampling }\end{array} \\
86 \\
87\end{array}$} & \multirow{3}{*}{$\begin{array}{c}\text { Tissue } \\
\text { collected }\end{array}$} & \multirow{3}{*}{$\begin{array}{c}\begin{array}{c}\text { Number of } \\
\text { sample (ind.) }\end{array} \\
10 \\
10\end{array}$} \\
\hline \multirow{5}{*}{$\begin{array}{l}\text { South } \\
\text { Sulawesi }\end{array}$} & \multirow{2}{*}{ Barru } & & & & & \\
\hline & & & & & & \\
\hline & \multirow{3}{*}{ Takalar } & April, 24 & TASY-1 & 25 & Gill and pleopod & 15 \\
\hline & & April, 25 & TAM -1 & 31 & Gill and pleopod & 10 \\
\hline & & April, 25 & TASY-2 & 31 & Gill and pleopod & 15 \\
\hline \multirow{2}{*}{ NTB } & \multirow{2}{*}{ Sumbawa } & \multirow{2}{*}{ June, 4} & SJHR-1 & 88 & Gill and pleopod & 10 \\
\hline & & & SJSB-1 & 79 & Gill and pleopod & 10 \\
\hline \multirow{5}{*}{ West Java } & Panimbang & April, 28 & РAH-B & PL-12 & Whole & 20 \\
\hline & \multirow{4}{*}{ Panimbang } & \multirow{2}{*}{ July, 1} & PJ A-1 & 93 & Gill and pleopod & 20 \\
\hline & & & PJB-2 & 95 & Gill and pleopod & 20 \\
\hline & & \multirow{2}{*}{ July, 3} & PJD-1 & 95 & Gill and pleopod & 20 \\
\hline & & & PJD-3 & 94 & Gill and pleopod & 20 \\
\hline \multirow{5}{*}{$\begin{array}{l}\text { South } \\
\text { Sulawesi }\end{array}$} & \multirow{2}{*}{ Takalar } & \multirow{2}{*}{ September, 20} & TSPL-1 & PL-10 & Whole & 15 \\
\hline & & & TSPL2 & PL-10 & Whole & 15 \\
\hline & \multirow{3}{*}{ Takalar } & November, 17 & TNSY-1 & 58 & Gill and pleopod & 10 \\
\hline & & November, 18 & TNSY-2 & 59 & Gill and pleopod & 10 \\
\hline & & November, 18 & TNSY-3 & 63 & Gill and pleopod & 10 \\
\hline \multirow{2}{*}{ NTB } & \multirow{2}{*}{ Sumbawa } & November, 27 & SNUR-1 & 78 & Gill and pleopod & 10 \\
\hline & & November, 28 & SNUR-2 & 90 & Gill and pleopod & 10 \\
\hline \multirow{6}{*}{ West Java } & \multirow{2}{*}{ Panimbang } & \multirow{2}{*}{ October, 6} & POSMI-1 & PL-9 & Whole & 15 \\
\hline & & & POSMI-2 & PL-9 & Whole & 20 \\
\hline & \multirow{4}{*}{ Panimbang } & \multirow{4}{*}{ December,12 } & PDSM I-D1 & 56 & Gill and pleopod & 10 \\
\hline & & & PDSM I-D3 & 56 & Gill and pleopod & 10 \\
\hline & & & PDSM I-A2 & 60 & Gill and pleopod & 10 \\
\hline & & & PDSM I-B1 & 60 & Gill and pleopod & 10 \\
\hline
\end{tabular}

chamber of POCKIT ${ }^{\mathrm{TM}}$ Nucleic Acid Analyzer which was run to begin the reaction program. The test result was shown on the screen after the reaction. The cleared protocol of analysis can be found in the operational procedure of The IQ Plus ${ }^{\mathrm{TM}}$ POCKIT System.

\section{RESULTS AND DISCUSSION}

All shrimp samples obtained from the farms and postlarvae (PLs) were analyzed by the IQ Plus ${ }^{\mathrm{TM}}$ POCKIT (Figure 1 and 2). The line marked with ? (Question) means that DNA or RNA virions were less than 10 copies and have to be re-analyzed (Figure 1 and 2). After re-analyzing, the samples were confirmed positive for WSSV and negative for IMNV. The bottom lines marked with positive signs both for WSSV and IMNV indicated good internal control for analyzing process (Figure 1 and 2). From the 20 shrimp farms and $5 \mathrm{PL}$ hatcheries that were randomly selected for this study, six shrimp farms were infected by WSSV and four farms by IMNV. Based on the information from the 20 farm owners, ten farms had a successful harvest, and the rest failed in different stage/days of culture (DOC) (Table 2).

A follow-up study was conducted in shrimp farms stocked with PLs positively tested for WSSV or IMNV by the IQ Plus ${ }^{T M}$ POCKIT. The successful harvest in shrimp farms stocked with tested PLs virus-free proves that the IQ Plus ${ }^{\top M}$ POCKIT system can be considered a good diagnostic tool and can be employed for virus screening in PL and broodstock as suggested by Koesharyani \& Gardenia (2015). The results showed that the prevalence of WSSV was $30 \%(6 / 20)$ and IM NV 


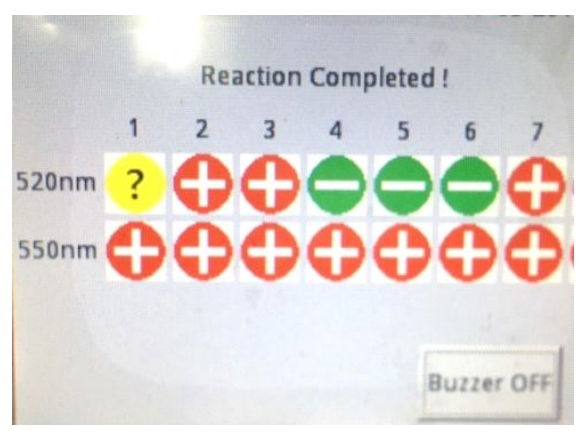

Figure 1. The IQ Plus ${ }^{T M}$ POCKIT for WSSV detection products from representative samples (Top Line) with WSSV-positive lines 2 and 3, WSSV negative lines 4-6, and control line 7. Marked ? in line 1 was DNA virion which was less than 10 copies and was re-analyzed and confirmed positive for W SSV, while bottom line indicates good internal control.

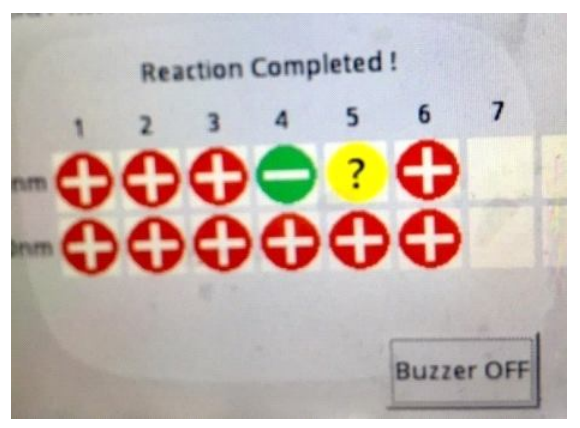

Figure 2. The IQ Plus ${ }^{\mathrm{TM}}$ POCKIT for IMNV detection products from representative samples (Top Line) with IMNV positive lines 1 to 3, IMNV negative lines 4, and line 5 marked? was DNA concentration which was less than 10 copies and was reanalyzed and confirmed negative, and positive control line 6 , while bottom line indicates good internal control.

was 20\%(4/20) while in PL's was 40\%(2/5) (Table 2). Interesting results revealed that WSSV positively infected the shrimp farms in Takalar while IMNV infected the shrimp farms only in Panimbang. The occurrences of WSSV and IMNV infection found in this study could be attributed to the contaminated PLS as showed in Table 2. WSSV is extremely virulent with a wide host range and targets various tissues of ectodermal and mesodermal origin (Prasad et al., 2017). This study suggests that all age groups and sizes of shrimp are affected by WSSV or IM NV in all kinds of aquaculture systems (extensive, semi-intensive, intensive, and super intensive). In this study, the shrimp samples from Takalar were collected from intensive and super intensive farms with stocking density between 150-750 ind. $/ \mathrm{m}^{3}$, while samples from Panimbang and Sumbawa were collected from extensive, semiintensive, and extensive farms with stocking densi- ties between $60-150$ ind. $/ \mathrm{m}^{3}$. Transmissions of WSSV and IMNV occurred vertically from the infected broodstock to larvae or horizontally through water or infected animals (Hossain et al., 2001; Otta et al., 2003). In the present study, positively tested WSSV or IMNV PL's stocked in farms had resulted in emergency harvest, while farms stocked with negative WSSV or IMNV had a normal harvest. However, some previously tested virus-free farms carried out emergency harvest that this study suggests a possible virus transmission at the same location via water from infected farms (Table 2).

Presently, WSSV is prevalent all over Asian countries (Corteel, 2013) while IM NV is prevalent only in Indonesia despite shrimp farming has been actively practiced in the nearby countries (Senapin et al., 2007; Taukhid \& Nur'aini, 2009). Indonesian shrimp farming practices use a higher rate of stocking densities 
Table 2. Screening results of shrimp (Litopenaeus vannamei) samples collected from different locations for WSSV and IMNV infections using IQ Plus ${ }^{\mathrm{TM}}$ POCKIT

\begin{tabular}{|c|c|c|c|c|c|c|}
\hline \multirow{2}{*}{ Locations } & \multirow{2}{*}{$\begin{array}{c}\text { Date of } \\
\text { Sampling } 2017\end{array}$} & \multirow{2}{*}{$\begin{array}{l}\text { Sample } \\
\text { Code }\end{array}$} & \multirow{2}{*}{$\begin{array}{l}\text { Life stage collected } \\
\text { (Days of culture /DOC) }\end{array}$} & \multirow{2}{*}{$\begin{array}{l}\text { No. of sample } \\
\text { (Ind.) }\end{array}$} & \multicolumn{2}{|c|}{ Status of virus } \\
\hline & & & & & WSSV & IMNV \\
\hline \multirow[t]{2}{*}{ Barru } & April. 24 & BAA-1 & 86 & 10 & - & - \\
\hline & April. 24 & BAA-2 & 87 & 10 & - & - \\
\hline \multirow[t]{3}{*}{ Takalar } & April. 25 & TASY-1 & 25 & 15 & + & - \\
\hline & April. 25 & TAM -1 & 31 & 10 & + & - \\
\hline & April. 25 & TASY-2 & 31 & 15 & + & - \\
\hline \multirow[t]{2}{*}{ Sumbawa } & June. 4 & SJHR-1 & 88 & 10 & - & - \\
\hline & June. 4 & SJSB-1 & 79 & 10 & - & - \\
\hline Panimbang & April. 28 & PAH-B & PL 12 & 20 & - & - \\
\hline \multirow[t]{4}{*}{ Panimbang } & July.1 & PJ A-1 & 93 & 20 & - & - \\
\hline & July.1 & PJB-2 & 95 & 20 & - & - \\
\hline & July.3 & PJD-1 & 95 & 20 & - & - \\
\hline & July. 3 & PJD-3 & 94 & 20 & - & - \\
\hline \multirow[t]{2}{*}{ Takalar } & Sep. 20 & TSPL-1 & PL10 & 15 & + & - \\
\hline & Sep. 20 & TSPL2 & PL10 & 15 & + & - \\
\hline \multirow[t]{3}{*}{ Takalar } & Nov. 17 & TNSY-1 & 58 & 10 & + & - \\
\hline & Nov. 18 & TNSY-2 & 59 & 10 & + & - \\
\hline & Nov.18 & TNSY-3 & 63 & 10 & + & - \\
\hline \multirow[t]{2}{*}{ Sumbawa } & Nov. 27 & SNUR-1 & 78 & 10 & - & - \\
\hline & Nov. 28 & SNUR-2 & 77 & 10 & - & - \\
\hline \multirow[t]{2}{*}{ Panimbang } & Oct. 6 & POSMI-1 & PL-9 & 15 & - & + \\
\hline & Oct. 6 & POSMI-2 & PL-9 & 20 & - & - \\
\hline \multirow[t]{4}{*}{ Panimbang } & Dec. 12 & PDSM I-D1 & 56 & 10 & - & + \\
\hline & Dec. 12 & PDSM I-D3 & 56 & 10 & - & + \\
\hline & Dec. 12 & PDSM I-A2 & 60 & 10 & - & + \\
\hline & Dec. 12 & PDSMI-B1 & 60 & 10 & - & - \\
\hline
\end{tabular}

in the range of 60 to 1,000 ind. $/ \mathrm{m}^{3}$ (Adiwijaya et al., 2008; Atjo, personal communication). High stocking density leads to increase chances of contact between the cultured individual and also escalates the probability of ingestion of WSSV and IMNV contaminated tissues (Graf et al., 2004). The onset of the disease is related to stress factors ranging from changes in salinity and temperature to rough handling during partial harvest or sampling by cast net. Temperature also plays a crucial role in the occurrence of diseases. Exposure to an elevated temperature could lead to excessive feeding which subsequently leads to elevated ammonia concentrations in the culture system (OIE, 2012). Indonesian climatic conditions like high atmospheric temperature can accelerate the stress conditions of shrimps thereby rendering them susceptible to WSSV or IMNV infection (Arafani et al., 2016). The present study demonstrated that the seeds stocked in Takalar or Panimbang shrimp farms were not free from WSSV and IM NV (Table 2). This was the main cause of disease outbreaks of WSSV and IMNV in these locations. The study also demonstrated that Indonesian shrimp farms located along the coastal areas are not free from WSSV or IMNV. This study is arguably the first report on shrimp DNA and RNA risk- based targeted disease surveillance of the viruses, at least for Indonesia. Based on the field observation, the PLs used in the farms were non-traceable. Some of the farms did not have proper biosecurity management with a poor environmental condition which increases the risks of infection of WSSV and IMNV. Therefore, a biosurveillance program is strongly recommended to be implemented by the government to avoid the spread of the viral diseases in other locations within the Indonesian region. Hatcheries producing PL should be requested to make sure that the $\mathrm{PLs}$ are free from the viruses and only PLs that are certified pathogen free (SPF) are allowed to be sold to farmers.

\section{CONCLUSION}

The prevalence of WSSV was 30\%(6/20) and IMNV was $20 \%(4 / 20)$, while on PL was $40 \%(2 / 5)$. In South Sulawesi (Takalar), shrimp samples were positive only for WSSV while West Java (Panimbang) samples were positive only for IMNV. Based on the research findings, this study recommends that a biosurveillance program has to be implemented in order to avoid the spread of the viral diseases to other locations within Indonesia. 


\section{ACKNOWLEDGMENTS}

The author thank the representative technicians, Mr. Saiful from Takalar farms, Mr. Mulyadi from Panimbang farms, and M r. Imron from Sumbawa farms for their help in collecting samples and share of information regarding their work experience in shrimp farms. This study was supported by the APBN 2017 annual budget through the Research Center for Fisheries.

\section{REFERENCES}

Adiwijaya, D., Supito, \& Sumantri, I. (2008). Application of semi-intensive culture technology of Shrimp (L. vannamei) at high salinity of brackish water ponds. Engineering of Coastal Aquaculture Media. Jepara Institute for Brackishwater Aquaculture Development, 7, 54-72.

Arafani, L., Ghazali, M.I., \& Muhamad, A. (2016). Detection of white spot syndrome virus in Litopenaeus Vannamei In Lombok Island using realtime polymerase chain reaction. Jurnal Veteriner, 17(1), 88-95.

Chen, S.N. (1995). Current status of shrimp aquaculture in Taiwan. In Broody, C.L. \& Hopkins, J.S. Swimming through trouble water. Proceeding of The Species Season on Shrimp Farming Aquaculture 95. USA: WAS Baton Rough Lousiana, p. 29-34.

Corteel, M. (2013). White spot syndrome virus infection in $\mathrm{P}$. vannamei and $\mathbf{M}$. rosenbergii: experimental studies on susceptibility to infection and disease. Thesis. Belgium: Ghent University, 105 pp.

Dantas, M.D.A., Chavante, S.F., Teixeira, D.I.A., Lima, J.P.M.S., \& Lanza, D.C.F. (2015). Analysis of new isolates reveals new genome organization and a hypervariable region in infectious myonecrosis virus (IMNV). Virus Res., 203, 66-71.

Ferasyi, H.R., Zulfikar, Z., Sugito, S., Muchlisin, Z.A., Razal, R., Nurliana, N., \& Al Azhar. (2015). A preliminary study of white spot syndrome virus (WSSV) infection on vannamei shrimp (Litopenaeus vannamei) cultured in semi-intensive ponds in Bireuen District of Aceh Province, Indonesia. AACL Bioflux, 8(5), 810-816.

Flegel, T.W. (2006). Detection of major penaeid shrimp viruses in Asia, a historical perspective with emphasis on Thailand. Aquaculture, 258, 133.

Graf, C., Gervais, N., Fernandes, M.P.C., \& Ayala, J.C. (2004). Transmissao da sindrome da necroseidiopatica muscular (NIM) em Litopenaeus vannamei. Aqualider. www. aqualider.com. br.

Hossain, M.S., Otta, S.K., Karunasagar, I., \& Karunasagar, I. (2001). Detection of white spot syndrome virus (WSSV) in wild-captured shrimp and in non-cultured crustaceans from shrimp ponds/ghers in Bangladesh by polymerase chain reaction. Fish Pathol., 36, 93-95.

Huang, J.X.L., Song, J.Yu., \& Yang, C.H. (1995). Baculoviral hypodermal and hepatopancreatic necroses study on the pathogen and pathology of the explosive epidemic diseases of shrimp. Marine Fisheries Research, 16, 1-10.

Karunasagar, I., Otta, S.K., \& Karunasagar, I. (1997). Histopathological and bacteriological study of white spot syndrome of Penaeus monodon along the west coast of India. Aquaculture, 153, 9-13.

Kilawati, Y. \& Maimunah Y. (2015). Environmental quality of intensive pond culture for Litopenaeus vannamei in relation with prevalence of white spot syndrome virus disease. Research Journal of Life Science, 02(01), 50-59.

Koesharyani, I. \& Gardenia, L. (2015). Rapid detection white spot syndrome virus (WSSV) and infectious myonecrosis virus (IMNV) by using portable or mobile polymerase chain reaction. Media Akuakultur, 10(1), 43-49.

Lightner, D.V., Pantoja, C.R., Poulos, B.T., Tang, K.F.J., Redman, R.M., Andreas, T., \& Bonami, J.R. (2004). Infectious myonecrosis (IMN): a new virus disease of Litopenaeus vannamei. In Aquaculture 2004, Book of Abstracts. USA: World Aquaculture Society, Baton Rouge, LA, 353 pp.

Lightner, D.V. (2011). Virus diseases of farmed shrimp in the Western Hemisphere (the Americas): A review. J. Invert. Pathol., 106, 110-130.

Nunan, L.M. \& Lightner, D.V. (2011). Optimized PCR assay for detection of white spot syndrome virus (WSSV). J. Virol. Methods, 171, 318-321.

Mahardika, K., Zafran, \& Koesharyani, I. (2004). Detec.tion of white spot syndrome virus (WSSV) in Penaeus monodon reared in hatchery and ponds in Bali and East Java using polymerase chain reaction (PCR) technique. Jurnal Penelitian Perikanan Indonesia, 10(1), 55-60 (In Indonesian with English abstract).

Octovianus, Sukoso, \& Yanuh, U. (2015). The prevalence of white spot syndrome virus on tiger shrimp (Penaeus monodon) traditional farming in Tarakan, Indonesia. J. Life Sci. Biomed., 5(5), 137-140.

OIE. (2010). Terrestrial aquatic animal health code. 19th ed. Office International des Epizooties, World Organisation for Animal Health, Paris, France, 14 pp.

OIE. (2012). Infectious myonecrosis virus. In Manual of diagnostic tests for aquatic animals. Office International des Epizooties, World Organisation for Animal Health, Paris, France, p. 138-147. 
OIE. (2015). OIE-listed diseases 2015. Office International des Epizooties, World Organisation for Animal Health, Paris, Surveillance for IMNV in Indian shrimp farms.

Otta, S.K., Karunasagar, I., \& Karunasagar, I. (2003). Detection monodon baculovirus (MBV) and white spot syndrome virus (WSSV) in apparently healthy Penaeus monodon postlarvae from India by polymerase chain reaction. Aquaculture, 220, 59-67.

Prasad, K.P., Shyam, K.U., Banu, H., Jeena, K., \& Krishnan, R. (2017). Infectious Myonecrosis Virus (IM NV) - An alarming viral pathogen to penaeid shrimps. Aquaculture, 477, 99-105.
Senapin, S., Phiwsaiya, K., Briggs, M., \& Flegel, T.W. (2007). Outbreaks of infectious myonecrosis virus (IMNV) in Indonesia confirmed by genome sequencing and use of an alternative RT-PCR detection method. Aquaculture, 266, 32-38.

Senapin, S., Phiwsaiya, K., Gangnonngiw, W., \& Flegel, T.W. (2011). False rumors of disease outbreaks caused by infectious myonecrosis virus (IMNV) in the whiteleg shrimp in Asia. J. Negat. Results BioM ed., 10, 1-10.

Taukhid \& Nur'aini, Y.L. (2009). Infectious myonecrosis virus (IMNV) in Pacific white shrimp (Litopenaeus vannamei) in Indonesia. ISR J. Aquac. (Bamidgeh), $61(3), 255-262$. 